\title{
The Relationship between Emotional Intelligence and the Academic Performance among Final Year under Graduates
}

\author{
Arockia Maraichelvi*, Sangeetha Rajan \\ Avinashilingam Institute for Home Science and Higher Education for Women, Coimbatore, Tamilnadu, India \\ *Corresponding Author: selvibru97@rediffmail.com
}

Copyright (C) 2013 Horizon Research Publishing All rights reserved.

\begin{abstract}
Emotional Intelligence (EI) has been a popular topic of debate in the field of education in general and management in particular. It is considered as a successful predictor of academic success/performance/achie vement. Researchers have claimed that EI predicts success at schools, and colleges/ universities. However, little empirical research has been conducted to test this assertion. In this study of survey research, the relationship of EI as measured by S.K. Mangal and Shubra Mangal's EI Inventory (MEII) and academic performance were examined in a sample of final year under graduate students $(\mathrm{N}=300)$. EI in its four specified domains namely Intrapersonal Awareness, Interpersonal Awareness, Intrapersonal Management and Interpersonal Management separately as well as totally was found to be positively associated with academic performance of the selected respondents. Also the total EI score showed a percentage of 7.5 per cent of the sample being emotionally intelligent. The significant ' $\mathrm{f}$ ' value has evidently showed that EI could predict academic performance of college students. The findings provide a further need on how to improve upon the academics of students. Also, the study has shown that emotional well - being could be emphasized on academic success. Implications and recommendations for developing EI among students are discussed.
\end{abstract}

Keywords Emotional Intelligence, Academic Performance, Intrapersonal Awareness, Interpersonal Awareness, Intrapersonal Management And Interpersonal Management

\section{Introduction}

Emotional intelligence is a confluence of developed abilities to (1) know and value self (2) build and maintain a variety of strong, productive and healthy relationships (3) get along and work well with others in achieving positive results;
(4) and effectively deal with the pressures and demands of daily life and work. The development of emotional intelligence is an intentional, active and engaging process [1]. Affective learning requires a person - centered process for student's growth and development. When emotional intelligence skills are the focus of learning, students are building human development behaviours that are intricately related to the positive outcomes of achievement, goal achievement and personal well- being.

Since 1990, Peter Salovey and John D. Mayer [2] have been the leading researchers on emotional intelligence. In their influential article "Emotional Intelligence," they defined emotional intelligence as, "the subset of social intelligence that involves the ability to monitor one's own and others' feelings and emotions, to discriminate among them and to use this information to guide one's thinking and actions".

Emotional Intelligence is not, in itself, sufficient to create optimal outcomes for youth. However, the way of emotional intelligence being used, both by youth and those who support them has a powerful effect on their lives. Emotional Intelligence appears to be a core ingredient that, when developed and well employed, has wide- ranging benefits for learning, relationships, and wellness [3].

Good academic performance is undoubtedly a research after the heart of educational psychologists. In their attempt to investigate what determines academic outcomes of learners, they have come with more questions than answers. In recent times, a prior literature has shown that learning outcomes (academic achievement and academic performance) have been determined by such variables as family, school, society and motivational factors [4]. In the same vein, Parker, et al [5] noted that much of the previous studies have focussed on the impact of demographic and socio - psychological variables on academic performance.

Various investigators have engaged in research designed to examine and apply emotional intelligence constructs within academic settings. Lam et al [6] investigated the notion that advanced emotional intelligence was correlated 
with greater individual performance, often above and beyond that associated with one's level of general intelligence. Jaeger [7] studied the effects of emotional intelligence instruction on academic performance and found out that a greater correlation exists between the emotional intelligence and academic performance. Likewise, Abisamra [8] reported that there is a positive relationship between emotional intelligence and academic achievement. He therefore canvassed for inclusion of emotional intelligence in the schools' curricula. Petrides, Frederickson and Furnham [9] argued that any investigation of the potential effects of emotional intelligence on academic performance must be pursued in a specific context.

Majority of the research suggests that emotional intelligence abilities lead to superior performance even in the most intellectual careers. The result states that 'Emotional Intelligence abilities were four times more important than IQ in determining professional success and prestige. There is a fairly substantial body of literature which suggests that as a measured construct, EI is predictive of performance in educational as well as industrial/ organizational settings [10]. There has been considerable research into the influence of emotional maturity on work performance of people, the impact of the same on academic performance has not been extensively delved into. There have indeed been a number of studies that demonstrate the predictive effects of emotional intelligence an academic achievement [11].

But by contrast a few of them have sought to provide evidence of limited relationship between students' emotional intelligence and their scores in their studies. Koifman [12]; and Zee, et al., [13] have shown no relationship between emotional intelligence and academic achievement. In essence, the importance of emotional intelligence on academic achievement has been found to be very significant. While some research has found emotional intelligence is not being correlated with academic performance the results has been mixed [14]. Nevertheless, and in spite of the studies reviewed, there is still a need to further investigate the relationship of emotional intelligence to academic achievement. Research indicating a close connection between emotional intelligence and academic performance is plethora.

The present research aims to fill up the lacunae of the researches held on the influence of Emotional Intelligence on Academic Performance and follows the words of Salovey and Mayer [10] who define EI as the ability to perceive and express emotions, assimilate them in thinking, understanding and reasoning, and regulate them in the self and others. Hence the domains of Emotional Intelligence as stated by Salovey and Mayer [10] namely Intrapersonal Awareness, Interpersonal Awareness, Intrapersonal Management and Interpersonal Management are considered and empirically examined for its relation with academic performance.

Subsequently, the term performance has got different connotations in the academic pursuit itself. However, Merriam Webster defines performance as the act of performing' (the action/work to be performed so as to accomplish or bring to completion), execution, accomplishment, fulfillment' etc. However, the term performance in the present research is related to the marks obtained by the subject in the first two years of their graduation and is coined to a single term as academic performance of the undergraduate students. With this background, the present study was conducted with the following objectives.

The objective for the present study were to:

To assess the relative effect of the measured Emotional Intelligence with the Academic Performance of the selected sample with regard to the four domains namely Intrapersonal Awareness, Interpersonal Awareness, Intrapersonal Management, and Interpersonal Management (totally and separately).

\section{Method}

The present study follows a descriptive research design/survey research to assess the role of emotional ntelligence on the academic performance of final year undergraduates. Three hundred college going adolescent girls of an institute for Higher Education at Coimbatore, Tamil Nadu was selected for the present research. A Standard Questionnaire by Mangal and Mangal for the assessment of Emotional Intelligence level of an individual (totally as well as separately on four domains Intrapersonal Awareness, Interpersonal Awareness, Intrapersonal Management and Interpersonal Management respectively) was being administered for the 300 respondents doing their final year undergraduation. The mark sheets of the selected sample till the 4th semesters' of their academic year were being computed and those marks were aggregated, and a mean of all those aggregated marks were collected. Then the mean of the semesters' marks had been graded, separating the high from the middle and the low achievers. Then an assessment of those grades with the Emotional intelligence scores (total as well as separately) of each student was being done, to see whether there is a relationship between Emotional Intelligence and Academic Performance. ANOVA technique is used to produce the result and find out the correlation between the Marks obtained which was graded and total emotional intelligence score and the four separate dimensions of emotional intelligence respectively. The summary of the findings were resolved and presented under the following heads.

\subsection{Findings of the Research}

The percentage distribution of the selected respondents based on the scores obtained in the four domains of emotional intelligence (total as well as separately) is associated with the mean marks scored by them in their previous semesters and presented under the five heads.

a. Intrapersonal Awareness Score on the academic 
performance

b. Interpersonal Awareness Score on the academic performance

c. Intrapersonal Management Score on the academic performance

d. Interpersonal Management Score on the academic performance

e. Total Emotional Intelligence Score on the academic performance

\section{a Intrapersonal Awareness score on the academic performance}

The Table 1 enumerate the relationship of intrapersonal awareness level on the academic performance of the selected sample.

Table 1. Relationship Between The Academic Performanceand The Intrapersonal Awareness Level Of The Selected Sample

\begin{tabular}{|c|c|c|c|c|c|}
\hline Intrapersonal & \multicolumn{2}{|c|}{$\begin{array}{c}\text { Awareness } \\
\text { Score }\end{array}$} & \multicolumn{2}{c|}{$\begin{array}{c}\text { Semester } \\
\text { marks obtained }\end{array}$} & \multirow{2}{*}{ f- Value } \\
\hline Grade & $\mathrm{N}$ & Percent & Mean & SD & \\
\hline $\begin{array}{c}\text { Very good } \\
(>=24)\end{array}$ & Nil & Nil & Nil & Nil & \\
\hline Good (20-23) & 69 & 23.0 & 73.92 & 8.21 & \multirow{2}{*}{$14.105^{* *}$} \\
\cline { 1 - 4 } $\begin{array}{c}\text { Average } \\
(14-19)\end{array}$ & 160 & 53.3 & 68.94 & 8.59 & \\
\hline Poor (10-13) & 63 & 21.0 & 64.74 & 10.03 & \\
\cline { 1 - 3 } $\begin{array}{c}\text { Very poor } \\
(<=9)\end{array}$ & 8 & 2.7 & 60.75 & 11.54 & \\
\hline
\end{tabular}

**-Significant at $1 \%$ level

The mean marks obtained by the good category were 73.92. This was followed by average academic scores (68.94) who also scored average in the intrapersonal awareness level. The poor and very poor performers in the academics (mean marks of 64.74 and 60.75 respectively) were also found to be poor and very poor in their intrapersonal awareness scores too. The calculated value 14.105 is being significant at $1 \%$ level.

\section{b. Interpersonal Awareness score on the academic performance}

The mean marks obtained were being compared with the interpersonal awareness score level of the selected sample and is tabulated in Table 2

Table 2. Relationship Between The Academic Performance And Interpersonal Awareness Level

\begin{tabular}{|c|c|c|c|c|c|}
\hline \multicolumn{3}{|c|}{ Interpersonal Awareness Score } & \multicolumn{2}{|c|}{$\begin{array}{l}\text { Semester marks } \\
\text { obtained }\end{array}$} & \multirow{2}{*}{$\begin{array}{l}\text { f- } \\
\text { Value }\end{array}$} \\
\hline Grade & $\mathrm{N}$ & Percent & Mean & SD & \\
\hline $\begin{array}{l}\text { Very } \\
(>=25)\end{array}$ & Nil & Nil & Nil & Nil & \multirow{5}{*}{$\begin{array}{l}14.274 \\
* *\end{array}$} \\
\hline Good (20-24) & 65 & 21.7 & 75.04 & 7.94 & \\
\hline $\begin{array}{l}\text { Average } \\
(14-19)\end{array}$ & 149 & 49.7 & 68.22 & 9.56 & \\
\hline Poor $(10-13)$ & 67 & 22.3 & 65.89 & 8.29 & \\
\hline $\begin{array}{l}\text { Very poor } \\
(<=9)\end{array}$ & 19 & 6.3 & 65.16 & 8.66 & \\
\hline
\end{tabular}

**-Significant at $1 \%$ level
Maximum mean marks of 75.04 is secured by students who are good in their level of emotional intelligence, followed by average (68.22), poor (65.89)and very poor academic performers (65.16) categorized under average, poor and very poor levels of emotional intelligence respectively.

\section{c. Intrapersonal Management score on the academic performance}

The Table 3 below provide a clear data on the association between the marks obtained by the selected sample on the intrapersonal management score level.

Table 3. Relationship Between The Academic Performance And The Intrapersonal Management Level

\begin{tabular}{|c|c|c|c|c|c|}
\hline \multicolumn{3}{|c|}{ Intrapersonal Management Score } & \multicolumn{2}{|c|}{$\begin{array}{l}\text { Semester marks } \\
\text { obtained }\end{array}$} & \multirow{2}{*}{$\begin{array}{l}f- \\
\text { Value }\end{array}$} \\
\hline Grade & $\mathrm{N}$ & $\begin{array}{l}\text { Perce } \\
\text { nt }\end{array}$ & Mean & SD & \\
\hline Very good $(>=25)$ & Nil & Nil & Nil & Nil & \multirow{5}{*}{$\begin{array}{l}5.901 \\
* *\end{array}$} \\
\hline Good (21-24) & 50 & 16.7 & 72.82 & 8.35 & \\
\hline Average (16-20) & 177 & 59.0 & 69.22 & 9.35 & \\
\hline Poor $(12-15)$ & 57 & 19.0 & 66.11 & 9.48 & \\
\hline Very poor $(<=11)$ & 16 & 5.3 & 64.66 & 9.94 & \\
\hline
\end{tabular}

**-Significant at $1 \%$ level

The f-value of 5.901 calculated to determine the relative effect of the level of intrapersonal management - a domain of emotional intelligence - on the academic performance is significant at 1 percent level. Also the table indicates that high score of 72.82 is scored by the respondents possessing good score on the intrapersonal management.

\section{d. Interpersonal Management score on the academic performance}

The marks obtained by the selected sample in correspondence to the interpersonal management score level are being calculated and is tabulated as in Table 4 .

Table 4. Relationship Between The Academic Performance And The Interpersonal Management Level

\begin{tabular}{|c|c|c|c|c|c|}
\hline \multicolumn{3}{|c|}{ Interpersonal Management Score } & \multicolumn{2}{|c|}{$\begin{array}{l}\text { Semester marks } \\
\text { obtained }\end{array}$} & \multirow{2}{*}{$\begin{array}{l}\text { f- } \\
\text { Value }\end{array}$} \\
\hline Grade & $\mathrm{N}$ & $\begin{array}{l}\text { Perce } \\
\text { nt }\end{array}$ & Mean & SD & \\
\hline Very good $(>=25)$ & Nil & Nil & Nil & Nil & \multirow{5}{*}{$\begin{array}{l}9.753 \\
* *\end{array}$} \\
\hline Good (21-24) & 27 & 9.0 & 72.65 & 9.84 & \\
\hline Average (16-20) & 154 & 51.3 & 70.06 & 9.21 & \\
\hline Poor (12-15) & 91 & 30.3 & 68.58 & 8.13 & \\
\hline Very poor $(<=11)$ & 28 & 9.3 & 60.84 & 10.49 & \\
\hline
\end{tabular}

**- Significant at $1 \%$ level

The table clearly typifies that a very low mean score in the semester marks of 60.84 is secured by the respondents who are found to be low in their level of interpersonal management. Also the $f$ value of 9.753 is significant at 1 percent level.

\section{e. Total emotional intelligence score on the academic} performance 
The Table 5 below explicates the relationship of emotional intelligence on the whole with the academic performance level (based on the mean marks obtained in the previous semesters), concerning the present study.

Table 5. Relationship Between The Academic Performance And The Total Emotional Intelligence Score

\begin{tabular}{|c|c|c|c|c|c|}
\hline \multicolumn{3}{|c|}{ Total Emotional Intelligence Score } & \multicolumn{2}{|c|}{$\begin{array}{l}\text { Semester marks } \\
\text { obtained }\end{array}$} & \multirow{2}{*}{$\begin{array}{l}\text { f- } \\
\text { Value }\end{array}$} \\
\hline Grade & $\mathrm{N}$ & $\begin{array}{l}\text { Percen } \\
\mathrm{t}\end{array}$ & Mean & SD & \\
\hline $\begin{array}{ll}\text { Very } & \text { good } \\
(>=88) & \end{array}$ & 5 & 1.6 & 81.10 & 6.93 & \multirow{5}{*}{$\begin{array}{l}11.235 \\
* *\end{array}$} \\
\hline Good (77-89) & 64 & 21.3 & 73.29 & 7.97 & \\
\hline $\begin{array}{l}\text { Average } \\
(63-76)\end{array}$ & 139 & 46.3 & 69.16 & 9.09 & \\
\hline Poor (49-62) & 79 & 26.3 & 65.67 & 8.65 & \\
\hline $\begin{array}{l}\text { Very poor } \\
(<=48)\end{array}$ & 13 & 4.3 & 61.35 & 12.43 & \\
\hline
\end{tabular}

**-Significant at $1 \%$ level

Overall five subjects were found to be extraordinary in their level of emotional intelligence and their academic mean score was 81.10 . The mean score is found to be decreasing gradually with reference to the level of emotional intelligence of the respondents. Also the f-value depicting the relative effect of emotional intelligence on the academic performance is found to be significant at 1 percent level.

\section{Discussion}

ANOVA was being used to find out the relationship between the mean marks obtained/ academic performance and the four domains of emotional intelligence namely intrapersonal awareness, interpersonal awareness, intrapersonal management and interpersonal management (both separately and totally) of the selected sample.

From the Table 1, it is indicative that, those who are good at Intrapersonal Awareness scores are good at academics too. The poor and very poor performers in the academics were also found to be poor and very poor in their intrapersonal awareness scores too. Thus the calculated $f$ value being significant at 1 percent level is indicative that there is a significant difference between the academic performance and the intrapersonal awareness score level of the selected sample. This result ensures that the first domain of emotional intelligence - Intrapersonal Awareness has a strong and positive influence on the academic performance of the adolescent girls.

The statistical ' $\mathrm{f}$ ' value in the Table 2 shows that the marks obtained by the selected sample is very much significant and has a positive impact on the interpersonal awareness score level. A considerable number among the selected sample are good at knowing about others' emotions so called as 'empathy'. The highest academic scorers are from the good categories that are good at academics, followed by average category, poor category and very poor category respectively. This table shows that increase in the interpersonal awareness score is proportional to the marks obtained and vice versa.
Hence, a student who is found to be high in the ability of understanding the emotions of others could also perform well in the academic settings.

It is evident from the Table 3 that the intrapersonal management skill of the selected sample being a significant contributor to the academic performance of the students. This lends a good credence to several studies which have shown positive correlation between intrapersonal management and academic performance [15]. This finding in turn suggests that a decline in intrapersonal management level may signify a decline in academic performance. It is certainly not surprising that children might perform better in college to the extent that they seek challenges, are curious or interested in their college work and desire to master tasks. Hence, this particular finding of a positive correlation is an expected outcome.

The ' $\mathrm{f}$ ' value calculated in correspondence of the association between interpersonal management skill and the mean marks of the selected respondents is significant at 1 per cent level as shown in Table 4. This finding plainly reiterates that a significant correlation was found between interpersonal management and academic performance of the students. Higher the ability of interpersonal management better is the academic performance. This result is in consonance with prior studies $[16,13,17]$, who found that adolescents who are particularly focussed on managing other emotions will do well on objective indicators of performance. It is certainly plausible that students who report a desire for hard work and aim to please their teacher with their hard work perform better in regular classroom assessments.

The analysis of data and the computed ' $\mathrm{f}$ ' value of 11.235 significant at 1 per cent level has evidently showed that emotional intelligence could significantly predict academic achievement of college students (Table 5). This finding is consistent with Parker et al [5] on the relationship between emotional intelligence and academic success. Similarly, Abisamra [8] had reported that there is a positive relationship between emotional intelligence and academic performance. Certainly and in consonant with the present finding, it can be ascertained that emotional intelligence determines to a great extent the academic performance of college going students.

This finding is easily explainable bearing in mind that emotional intelligence competencies, such as ability to regulate one's feelings, problem solving, intrapersonal and interpersonal skills are highly germane to academic success. For instance, a student who is adept in emotional management could use such skills to ward off stress and anxiety associated with test taking and examination. Furthermore ability to display interpersonal and intrapersonal skills may assist students to seek academic help from teachers, peers and resource persons.

\subsection{Implications of the study}

The study has implication for the curriculum developers to integrate emotional intelligence into the curriculum of school to college students. The teachers, counsellors and 
educational psychologists should encourage the development of a strong achievement motivation in the students through the provision of appropriate counselling intervention programmes and enabling environment. By doing so, the academic performance of the students could be improved barring all other teaching - learning obstacles.

The sub - factors of emotional intelligence, consistently predict academic performance, as per the present finding which itself has interesting implications. It is an accepted finding that emotional intelligence is a strong predictor of job performance. Yet, schools and admission tests continue to put a significant emphasis on cognitive ability, when it explains very little of achievement in the workplace or in life. In graduate programs and cognitively demanding careers, such as engineering, the selection process focuses primarily on intellectual abilities, while emotional intelligence is neglected. Therefore, graduate programs and competitive companies could consider incorporating such an emotional intelligence construct in the selection process.

And it is strongly recommended that business schools consider adding practical courses that would help students function at a higher level of emotional intelligence and which would ultimately improve employee performance and interactions in the workplace.

\section{Limitation}

Although the sample size for this study was relatively big, the fact still remains that it did not represent the totality of students. Also the other gender was not examined. Thus a note of caution needs to be sounded when generalizing the study's findings. Despite this limitation, the findings of the study have provided a further need on how to improve upon the academics of students. In particular, the study has shown that emotional well - being could be emphasized on academic success.

\section{REFERENCES}

[1] Nelson, D., and Low, G. (2003), Emotional intelligence: Achieving academic and career excellence, Upper Saddle River, PA: Prentice Hall, Pp 12, 102.

[2] Salovey, P. \& Mayer, J .D. (1990).Emotional Intelligence, imagination, cognition, and personality, Baywood Publishing Co., pp 185-211.

[3] Six Seconds, Emotional Intelligence Network, http://www.6seconds.org/2013/04/24/fog-how-to-use-emotio nal-intelligence-free-poster/.

[4] Aremu, A. O. (2004), Psychological and Sociological determinant of academic achievement of Nigeria Adolescents, Ife Psychologia, An International Journal of Psychology in Africa, 12, (2), pp 149-161.

[5] Parker. J. D. A., Creque. Snr. R. E., Barnhart. D. L., Harris. J. I., Majeski. S. A., Wood. L. M., et al., (2004), Academic
Achievement in high School: Does Emotional Intelligence Matter?, Personality and Individual Differences, 37(7), pp 1321- 1330 Personality, 9, 195-211.

[6] Lam (2001). Emotional intelligence: Emotional intelligence: The role of transformative learning in academic excellence. (Vol. XIII, No. 2, pp. 7-10), TEXAS STUDY of Secondary Education.

[7] Jaeger (2003), A conceptual framework for emotional intelligence in education: Factors affecting student achievement, (Vol. XIV, No. 2, pp 41-44), Unpublished doctoral dissertation, Texas A\&M University-Kingsville.

[8] AbiSamra, N. (2000), The Relationship between Emotional Intelligence and Academic Achievement in Eleventh Graders, Research in Education, FED, pp 620-661.

[9] Petrides. K. V., Frederickson and Furnham. A, and. (2005), On the dimensional structure of emotional intelligence, Personality and Individual Differences, 42, pp 313-320.

[10] Goleman, D. (2003) Apples and Applesauce, Issues and Recent Developments in Emotional Intelligence, 1(3), pp 425-448.

[11] Marquez Martin and Bracket, Adeyemo et.al., 2006, Emotional Intelligence and Academic Achievement, The Handbook of Emotional Intelligence, San Francisco: JosseyBass, 18, pp 304-323.

[12] Koifman, 1998, Effect of emotional intelligence on academic achievement, Emotional intelligence: Achieving academic and career excellence. (Vol. XXIV, No.7, pp 65-150), Upper Saddle River, NJ: Prentice-Hall.

[13] Zee, K., Thijs, M. and Schakel, L. (2002), The relationship of emotional intelligence with academic intelligence and the Big Five. Eur. J. Pers., 16: 103-125.

[14] Corrie et. al., 2004, Emotional Intelligence and Academic Achievement, New Bossy Publications, UK, (2nd Ed.), pp 105- 165 .

[15] Gottfried, 1990, Interpersonal skills and Academic performance, Journal of Personality and social psychology, (No. 9, pp 45-103), New York, Grosset/ Putnam.

[16] Baron-Cohen, S. (2003). The essential difference: men, women and the extreme male brain. London: Allen Lane.

[17] Derksen, J., Kramer, I., \& Katzko, M. (2002). Does a self-report measure for emotional intelligence assess something different than general intelligence? Personality and Individual Differences, 32, 37-48. 